\title{
PRINCIPLES AND CHARACTERS OF RELIGIOUS MODERATION IN CHRISTIAN RELIGIOUS EDUCATION
}

\author{
Doli Alberto Sagala \\ Penyelenggara Bimas Kristen Kementerian Agama Kota - Surabaya \\ E-mail: dolialberto@kemenag.go.id
}

\begin{abstract}
This study aims to describe the inculcation of the value of religious moderation in Christian Religious Education. The research method used is descriptive qualitative. This study concludes that the cultivation of the value of religious moderation in Christian Religious Education is based on the principles of religious moderation: (1) fairness, (2) balance and character of religious moderation: (1) wisdom (2) sincerity (3) courage
\end{abstract}

Keywords: Religious Moderation, Christian Religious Education, Principles, Character.

\section{INTRODUCTION}

The diversity possessed by the Indonesian nation includes various ethnicities, languages, religions and true cultures which can bind people's lives but can also be a cause of conflict in society. And in its management, it is certain that there is a need for deep communication interaction in the community. So it is necessary to have a specific deepening of what the distinctive characters exist in each society, so it is necessary to know what is the unifying force in the midst of diversity. Diversity is the basis of moderation, living in diversity is not an option but rather a provision that we must live by, exercising moderation is the art of living guided by scripture.
The basic idea of moderation is to look for similarities not to sharpen differences Understanding and knowledge about diversity is very important because with it a religious adherent can take a middle path. Because an extreme attitude occurs when someone does not know other alternative truths that can be applied. Therefore, religious moderation is an important point of view in religion. Because in fact religious moderation is the essence of religion and its implementation is a necessity in order to create intra and interreligious harmony. The diversity possessed by the Indonesian nation includes various ethnicities, languages, religions and cultures which can actually bind 
people's lives but can also be the cause of conflicts in society. Each element must have a moderate attitude, so that this awareness becomes the basis of a moderate attitude. Moderation is taken from the Latin moderatio, which means moderation (not excess). The word also means self-control (from an attitude of very strengths and weaknesses).

(Moderation, Ministry of Religion Research and Development Agency, 2019: 8)

The KBBI Dictionary explains that the meaning of the word moderation as a reduction in violence is said to be "a person is moderate". The sentence means that "the person is acting naturally, mediocre and not extreme".

In English, the word moderation is used in the sense of average or nonaligned. Or in other words, a balanced attitude means firm, not harsh because it always sides with justice. Balance can be considered as a form of perspective to do something sufficiently, not excessive.

A balanced attitude means avoiding being absolutely selfish on the one hand and absolutely selfless on the other. Pursuing personal happiness on the one hand and maintaining mutual happiness on the other.

\section{RESEARCH METHOD}

In this study, the authors used a qualitative descriptive method, and were analyzed. Sources of data through library submissions \& qualitative data collection through interviews with Christian Religious Education Teachers then collected and processed and still assessing the phenomenology in the field.

\section{RESULTS AND DISCUSSION}

The basic asset of moderation is diversity, living in diversity is not an option but rather a provision that we must live by, practicing moderation is a life that has been guided by scripture. Indonesia, which stretches from Sabang to Merauke, has a wealth of islands, ethnicities, languages, religions, races, groups and cultures that are very diverse. This has become a very large cultural base. Indonesian society is plural and is a plus for the nation. To manage this cultural diversity requires a moderate attitude or in the middle. This attitude must be possessed by every element, so that this awareness becomes the basis of a moderate attitude. Moderation is taken from the Latin moderatio, which means moderation (not excess). The word also means self-control (from an attitude of very strengths and weaknesses). The KBBI Dictionary explains that the meaning of the word moderation as a reduction in violence is said 
to be "a person is moderate". The sentence means that "the person is acting naturally, mediocre and not extreme". In English, the word moderation is used in the sense of average or non-aligned.

Which means promoting balance in terms of beliefs, morals and character in everyday life. In Arabic, moderation is known as the word wasathiyah, which has the equivalent meaning of the word tawassuth (middle). In the religious moderation book published by Litbang (2019), the opposite word for religious moderation is excessive, the equivalent of words in English is extreme, excessive in English. In the context of religion, this exaggerated definition can be applied to refer to people who have an extreme attitude, and exceed the limits and provisions of religious law. Still in the Ministry of Religion's R\&D book, religious moderation must be understood as a balanced or intermediate religious attitude, not radical or polar liberalism.

The meaning of this balance can prevent all from being overly extreme, so that the value of moderation described earlier is a solution to the two poles of extremes, namely the poles of radicalism or the poles of liberalism. Religious moderation is something that must be undertaken by every religious community, and in the long term religious moderation has been included in the priorities of the 2020-2024 National Medium Term Development Plan (RPJMN Principles of Religious Moderation

The description of moderation principles in the religious moderation book of the Ministry of Religion Research and Development (2019) is (1) fair, (2) balance. (1) just, means not being partial or taking sides with the truth, it can also be interpreted as someone who is not partial, but takes sides with the truth. (2) namely balance, the term balance is described with a perspective, attitude and commitment to always side with justice, humanity and equality.

A balanced attitude means firm, not harsh because it always takes the side of justice, taking sides does not take the rights of others to the detriment. Balance can be considered as a form of perspective to do something sufficiently, not excessive. A balanced attitude means avoiding being absolutely selfish on the one hand and absolutely selfless on the other. Pursuing personal happiness on the one hand and maintaining mutual happiness on the other (kamali 2015: 31).

\section{Character of Religious Moderation}

Three characters of religious moderation: (1) wisdom, (2) sincerity, (3) courage, it can be said that wisdom in 
choosing the middle way, as well as sincerity \& courage in every attitude. Every human being has extensive knowledge that is sufficient so that he can act wisely, resist temptation, be sincere, and not selfish with his own interpretation of the truth and dare to convey his views based on science.

The prerequisites for religious moderation are the necessity of having comprehensive knowledge of religious rituals, (the principle of ease of practice in religion, as far as practice is possible) and an open attitude in understanding diversity and differences. In a state, this character of moderation, at the beginning of independence, could unite independence figures who were politically reticent, various religions, and religious beliefs.

\section{Christian Education}

In Law No. 20 of 2003, where the purpose of education is "developing the ability and shaping the character and civilization of a nation with dignity in order to educate the nation's life, aims to develop the potential of students to become human beings who believe and laugh at God Almighty, have good character, healthy, knowledgeable, competent, creative, independent, and a democratic and responsible citizen. It is clear that religious values are contained in this goal and it is hoped that education will be able to give big changes in the lives of the people. In his book, Demsy Jura (2020: 15) reveals that in fact every individual needs education that will enable him to become a human being and have the ability to manage life and lead a better life. According to Delipeter Lase \& etty D. Hulu, Christian Religious Education is teaching someone to know who Jesus Christ is as a role model in it.

Whereas in the Sahunderstanding (2019) study, Christian Religious Education is a process of teaching and learning that is based on the Bible, centered on Christ and depends on the power of the holy spirit which guides each person at a growth level through current teaching towards knowing and experiencing God's plan and will through Christ in every aspect and equips them for effective ministry centered on Christ the teacher.

In a broader perspective, Jura (2020: 17) says that Christian Religious Education is based on the Bible, as the word of God and Jesus Christ as an exemplary person in it, through Christian Religious Education material it is hoped that Christian Education teachers can provide enlightenment about knowing Christ to students.

Therefore, Christian Religious Education learning materials need to accommodate the topic of religious moderation so that active participation as Christian Education teachers for the 
community in general is for moderate religion. In the context of Christianity, religious moderation can be a way of looking to mediate the extremities of Christian interpretation that are understood by some followers. One of the tips to strengthen Religious moderation is the maximum possible interaction between one religion and another, between one sect and another within the internal religious community. In Christianity, this concept of moderation is very identical with the character of love. How Jesus teaches the principle of love in the Gospel of Mark 12: 28-31 and the teaching of the apostle Paul in 1 Corinthians 13: 1-13 about how faith, hope and love and the greatest is love. Moderation of religion actually becomes significant in building relations both externally and internally in creating harmony between various denominations within one religion. It is important to develop strategic steps internally by involving and maximizing the role of all parties.

Cultivating the principle of religious moderation in Christian Religious Education The process of cultivating the principle of religious moderation is implemented in teaching and learning activities, where Christian Education teachers have indirectly included the principle of fairness and the principle of balance in learning that is conveyed to students. The internalization has been carried out because the principle of fairness and the principle of balance already exists in learning themes that have been conveyed to students so far because the process of internalization is a process that lasts a lifetime, especially when students start learning.

\begin{tabular}{|c|c|c|}
\hline & $\begin{array}{l}\text { Principle of } \\
\text { Moderation }\end{array}$ & Value Cultivation \\
\hline \multirow{6}{*}{$\begin{array}{l}\text { Description of } \\
\text { Religious } \\
\text { Moderation }\end{array}$} & \multirow{3}{*}{ Fair } & $\begin{array}{l}\text { Psalm ll: } 7 \text { In the Learning Material, the Meaning of God is Just in } \\
\text { Human Life }\end{array}$ \\
\hline & & $\begin{array}{l}\text { Psalm 103: } 6 \text { Cultivation of Justice for Those Who Are Oppressed / } \\
\text { Oppressed, Those Who Do Oppression Receive Evil Wages }\end{array}$ \\
\hline & & $\begin{array}{l}\text { Matthew 22: } 39 \text { Be Fair to Others Through Loving Your neighbor } \\
\text { as Thyself }\end{array}$ \\
\hline & \multirow{3}{*}{ Balance } & $\begin{array}{l}\text { Mark l: } 35 \text { Balance in being able to live begins in the morning by } \\
\text { praying during quiet time, teaching and learning activities also } \\
\text { begin with prayer during quiet time for the students }\end{array}$ \\
\hline & & $\begin{array}{l}\text { Galatians 6: 8 Teaching Whoever Sows to the Flesh, He will Reap } \\
\text { the Habits in the Flesh, But whoever Sows to the Spirit, He Will } \\
\text { Reap Eternal Life from the Spirit }\end{array}$ \\
\hline & & $\begin{array}{l}\text { Proverbs 4: } 25 \text { The Teaching of Righteousness Not Oblique Right } \\
\text { and Left "Let Your Eyes Look Ahead" }\end{array}$ \\
\hline
\end{tabular}

\section{Cultivating the character of religious}

\section{moderation in Christian Religious}

Education Wisdom, sincerity, courage are standard characters in the religious moderation book of the Ministry of Religion in instilling the value of religious moderation.

(1) wisdom which is an attitude that is produced through a long process of life is of course also based on a deep understanding of religious knowledge

(2) sincerity in attitude is complemented by virtuous life in society

(3) courage in this attitude is interpreted as 
courage which is full of care, especially in understanding conflict in the context of teaching and learning activities.

\begin{tabular}{|c|c|c|}
\hline & $\begin{array}{l}\text { Moderation } \\
\text { Characters }\end{array}$ & Value Cultivation Implementation \\
\hline \multirow{9}{*}{$\begin{array}{l}\text { Description of } \\
\text { Religious } \\
\text { Moderation }\end{array}$} & \multirow{3}{*}{ Wisdom } & $\begin{array}{l}\text { Example in Teaching and Learning Activities, Acts 2: } 43-47 \\
\text { Building Relationships with God in Every Learning Activity }\end{array}$ \\
\hline & & $\begin{array}{l}\text { Hebrerrs } 20: 25 \text { Teachers as role models / examples in worship for } \\
\text { students }\end{array}$ \\
\hline & & Be flexible and adapt in the teaching and learning process \\
\hline & \multirow{3}{*}{ Sincerity } & $\begin{array}{l}\text { Isaiah 33: 6, Eph. 1:17 Be wise in dealing with problems in teaching } \\
\text { and learning activities }\end{array}$ \\
\hline & & $\begin{array}{l}\text { Colossians 3: 12-13 Patience Is Able to Face Different Degrees of } \\
\text { Practice }\end{array}$ \\
\hline & & $\begin{array}{l}\text { Romans 13:13 Abstain From Activities That Are Contrary to the } \\
\text { Teachings of Jesus Christ }\end{array}$ \\
\hline & \multirow{3}{*}{ Bravery } & $\begin{array}{l}2 \text { Timothy 3:16 Becomes the Bible as the Center in Teaching and } \\
\text { Learning Activities }\end{array}$ \\
\hline & & $\begin{array}{l}\text { Conreying Testimony of Faith in Teaching and Learning Activities } \\
\text { to Students }\end{array}$ \\
\hline & & $\begin{array}{l}\text { Encouraging Students To Entrust Life And Struggles Into God's } \\
\text { Hands }\end{array}$ \\
\hline
\end{tabular}

\section{CONCLUSION}

The formulation of the Ministry of Religion on religious moderation which seeks to make religion understood and practiced by all people with a moderate form of implementation and a return to the middle (neither to the radical poles nor to the poles of liberalism) with the values of the principles and character of religious moderation.

The principle of religious moderation has basically been implemented indirectly in Christian Religious Education merging into one with the character of Christian Religious Education which is sourced from the Bible, where Christian Religious Education teaches that every human being experiences life like Jesus Christ who is the savior, interpret life and develop his faith similar to Christ.

Likewise, the character of religious moderation has also existed in the learning character of Christian Religious Education and is applied in teaching and learning activities from Christian Education teachers to students. Religious moderation has also been included in the priorities of the National Medium Term Development Plan (RPJMN) for 2020-2024, it is hoped that it will soon be manifested as part of the Christian Religious Education curriculum.

\section{REFERENCES}

Badan Litbbang dan Diklat Kementerian Agama RI. 2019. Moderasi Beragama.

Direktorat Jenderal Bimas Kristen Kementerian Agama RI. 2019 Moderasi beragama dalam persfektif Kristen. Jakarta. Gunung mulia.

Demsy (2020) Pendidikan Agama Kristen dalam rimba kontemplasi, Jakarta : UKI Press.

Kamali, mohamad hasyim, 2015 : the middle path of moderation in islam, the qur'anic principle of wasathiyah, oxford: oxford university press.

Lase D \& Hulu E.D (2020) Dimensi spiritualitas dalam kompetensi kepribadian guru Pendidikan Agama Kristen.

SUNDERMAN : Jurnal Ilimiah Teologi, Pendidikan, Sains, Humaniora dan Kehidupan 13 (1), 13-25)

Rencana Pembangunan Jangka Menengah 
Journal Didaskalia

E-ISSN: 2621-8054

P-ISSN: 2622-1667

Nasional (RPJMN) tahun 2020-2024.

Sahertina, Marthen (2019) Pendidikan

Agama Kristen dalam sudut pandang John

Dewey, Jurnal teruna Bhakti Vol 1 No.2

Undang-undang no 20 tahun 2003 tentang

sistem pendidikan nasional. 